\title{
Impacts of Permafrost Degradation on Carbon Stocks and Emissions under a Warming Climate: A Review
}

\author{
Huijun Jin ${ }^{1,2, *}$ and Qiang Ma ${ }^{2,3, *}$ \\ 1 School of Civil Engineering, Institute of Cold-Regions Science and Engineering, Northeast-China Observatory \\ and Research-Station of Permafrost Geo-Environment (Ministry of Education), Northeast Forestry University, \\ Harbin 150040, China \\ 2 State Key Laboratory of Frozen Soils Engineering, Northwest Institute of Eco-Environment and Resources, \\ Chinese Academy of Sciences, Lanzhou 730000, China \\ 3 School of Hydraulic Engineering and Electric Power, Heilongiiang University, Harbin 150040, China \\ * Correspondence: hjjin@nefu.edu.cn (H.J.); maqiang8002@1zb.ac.cn (Q.M.)
}

Citation: Jin, H.; Ma, Q. Impacts of Permafrost Degradation on Carbon Stocks and Emissions under a Warming Climate: A Review. Atmosphere 2021, 12, 1425. https:// doi.org/10.3390/atmos12111425

Academic Editors: Alexey V. Eliseev

Received: 18 September 2021

Accepted: 26 October 2021

Published: 29 October 2021

Publisher's Note: MDPI stays neutral with regard to jurisdictional claims in published maps and institutional affiliations.

Copyright: (c) 2021 by the authors. Licensee MDPI, Basel, Switzerland. This article is an open access article distributed under the terms and conditions of the Creative Commons Attribution (CC BY) license (https:// creativecommons.org/licenses/by/ $4.0 /)$.

\begin{abstract}
A huge amount of carbon (C) is stored in permafrost regions. Climate warming and permafrost degradation induce gradual and abrupt carbon emissions into both the atmosphere and hydrosphere. In this paper, we review and synthesize recent advances in studies on carbon stocks in permafrost regions, biodegradability of permafrost organic carbon (POC), carbon emissions, and modeling/projecting permafrost carbon feedback to climate warming. The results showed that: (1) A large amount of organic carbon $(1460-1600 \mathrm{PgC})$ is stored in permafrost regions, while there are large uncertainties in the estimation of carbon pools in subsea permafrost and in clathrates in terrestrial permafrost regions and offshore clathrate reservoirs; (2) many studies indicate that carbon pools in Circum-Arctic regions are on the rise despite the increasing release of POC under a warming climate, because of enhancing carbon uptake of boreal and arctic ecosystems; however, some ecosystem model studies indicate otherwise, that the permafrost carbon pool tends to decline as a result of conversion of permafrost regions from atmospheric sink to source under a warming climate; (3) multiple environmental factors affect the decomposability of POC, including ground hydrothermal regimes, carbon/nitrogen $(\mathrm{C} / \mathrm{N})$ ratio, organic carbon contents, and microbial communities, among others; and (4) however, results from modeling and projecting studies on the feedbacks of POC to climate warming indicate no conclusive or substantial acceleration of climate warming from POC emission and permafrost degradation over the 21st century. These projections may potentially underestimate the POC feedbacks to climate warming if abrupt POC emissions are not taken into account. We advise that studies on permafrost carbon feedbacks to climate warming should also focus more on the carbon feedbacks from the rapid permafrost degradation, such as thermokarst processes, gas hydrate destabilization, and wildfire-induced permafrost degradation. More attention should be paid to carbon emissions from aquatic systems because of their roles in channeling POC release and their significant methane release potentials.
\end{abstract}

Keywords: climate warming; carbon stocks; permafrost; atmosphere; aquatic systems

\section{Introduction}

A large quantity of carbon (C) (1460-1600 Pg C) is stored in permafrost regions in the northern hemisphere [1,2]. Permafrost organic carbon (POC) amounts to nearly twice the size of the carbon pool in the atmosphere $(\sim 730 \mathrm{Pg} \mathrm{C})$, or about thrice that of terrestrial vegetation $C[3,4]$. Clathrates in terrestrial and subsea permafrost are also included in this permafrost $C$ inventory. Carbon stocks in permafrost regions are a globally important $\mathrm{C}$ pool in climate-sensitive cold regions, such as the arctic, boreal, alpine, and high-plateau regions [5]. In recent decades, persistent climatic warming at an average rate of $0.060{ }^{\circ} \mathrm{C} \cdot \mathrm{yr}^{-1}$ has been extensively reported in high-latitudinal regions, which is twice faster than that of the global average [6]. On the Qinghai-Tibet Plateau (QTP), the largest 
expanse of elevational permafrost on Earth, the average rate of climate warming was at $0.045^{\circ} \mathrm{C} \cdot \mathrm{yr}^{-1}(1980-2018)$ [7].

Climate warming will unlock organic carbon and nitrogen sequestered in permafrost, emitting large quantities of greenhouse gases, such as $\mathrm{CO}_{2}, \mathrm{CH}_{4}$, and $\mathrm{N}_{2} \mathrm{O}$, by microbial decomposition, into the atmosphere, and forming positive feedback to climate warming $[2,3,8]$. Currently, carbon fluxes in Arctic permafrost regions are estimated as a $\mathrm{CO}_{2}$ sink at rates of $0.3-0.6 \mathrm{Pg} \mathrm{C} \mathrm{yr}^{-1}$ and a $\mathrm{CH}_{4}$ source at rates of $23-75 \mathrm{TgC} \cdot \mathrm{yr}^{-1}$ and they are projected to be both $\mathrm{CO}_{2}$ and strengthened $\mathrm{CH}_{4}$ sources by 2100 [9]. Another portion of POC will be delivered into the aquatic ecosystems in forms of particulate organic $\mathrm{C}$ (PTOC) and dissolved organic C (DOC) (e.g., [10-12]). Released POC will go into fluvial systems and eventually be deposited into deep oceans, altering the terrestrial-oceanic $\mathrm{C}$ distribution. Organic $\mathrm{C}$ in aquatic systems can also be further microbially converted into $\mathrm{CO}_{2}$ or $\mathrm{CH}_{4}$ [13-15].

Configurations of permafrost degradation can be characterized by gradual degradation or abrupt permafrost thaw [16]. The former, such as the top-down degradation, shrinkage of permafrost extent, and others, will induce relatively slow, yet extensive $C$ emissions from permafrost regions [2]. By pooling observations from more than 100 Arctic field sites, Natali et al. (2019) estimated an average release of $1662 \mathrm{Tg} C$ (2003-2017) from permafrost each winter, double that of past estimates [17]. However, abrupt permafrost degradation will induce imminent $C$ release to both the atmosphere and aquatic systems. A mega-slump in Bataigaika, upper Yana River Basin, Eastern Siberia, may have emitted millions of tons of $\mathrm{CH}_{4}$ into the atmosphere over a very short time [18]. Arctic coastal lowlands consist of organic- and ice-rich permafrost and are endowed with a significant DOC storage [19]. Tanski et al. (2019) pointed out that the erosion and recession of these coasts could release a large amount of permafrost carbon directly into the Arctic Ocean [14].

Carbon emission in responding to permafrost degradation is impacted by a synergy of multiple environmental factors (e.g., [3,8,20-22]). Mutual interactions between these environmental factors and microbial activities in the soil are complex [23]. Without an adequate understanding of the mechanisms of microbial activities in responding to (cryo-) pedogenesis, it is difficult to accurately model, simulate, and predict $C$ emission under scenarios of permafrost thawing [24]. Thus, in this paper, we review and synthesize recent studies on and research advances in $C$ stock and its stability in permafrost regions, biodegradability of organic $C$ in permafrost regions, $C$ emission impacted by permafrost degradation, and model projecting/modeling of permafrost $C$ feedback to climate warming. This study can help provide a baseline understanding on POC stock and its positive feedbacks to climate warming and close the research gaps on permafrost $C$ dynamics.

\section{Carbon Stocks in Permafrost Regions}

\subsection{Soil Organic Carbon (SOC) Stocks in Permafrost Regions}

Soil is the largest organic $C$ pool in terrestrial ecosystems. It is also the most important terrestrial organic $C$ pool in permafrost regions. Stocks of soil organic carbon (SOC) in permafrost regions have been intensively studied in recent years (e.g., [1,25-35]). With different estimation methods or models, associated soil depths or horizons, recent geological time, and ecosystem types, SOC stocks have been estimated in different permafrost regions. Parts of these estimations are listed in Table 1. 
Table 1. Distribution of soil organic carbon (SOC) in permafrost regions.

\begin{tabular}{|c|c|c|c|c|c|c|}
\hline Regions & $\begin{array}{l}\text { Soil Horizons } \\
\text { or Depths (m) }\end{array}$ & $\begin{array}{l}\text { Time } \\
\text { Period }\end{array}$ & $\begin{array}{l}\text { Areal Extent } \\
\left(10^{6} \mathrm{~km}^{2}\right)\end{array}$ & $\begin{array}{c}\text { Soil Organic } \\
\text { Carbon Density } \\
\left(\mathrm{kg} \cdot \mathrm{m}^{-3}\right)\end{array}$ & $\begin{array}{c}\text { Carbon Stock } \\
(\operatorname{Pg} C)\end{array}$ & References \\
\hline \multicolumn{7}{|c|}{ Latitudinal permafrost regions (1460-1600 $\mathrm{Pg} C$ ) } \\
\hline \multicolumn{7}{|l|}{ Arctic/Antarctic } \\
\hline Arctic & $0-0.25$ & present & 5.6 & 18.81 & $\sim 26.33$ & [26] \\
\hline High Arctic & $0-0.3$ & present & 1.068 & 31.21 & $10 \pm 3$ & [1] \\
\hline High Arctic & $0-1$ & present & 1.068 & 22.47 & $24 \pm 8$ & [1] \\
\hline High Arctic & $1-2$ & present & 1.068 & 6.55 & $7 \pm 5$ & [1] \\
\hline High Arctic & $2-3$ & present & 1.068 & 2.81 & $3 \pm 3$ & [1] \\
\hline Yedoma $^{1}$ & $>3$ & present & 1.387 & $4-17$ & $58-371$ & [27] \\
\hline Yedoma & $>3$ & $\mathrm{LGM}^{2}$ & 1.32 & 16.32 & $390-446$ & [28] \\
\hline Siberian yedoma & $>3$ & present & 1 & 18 & 450 & [4] \\
\hline Siberian yedoma & $>3$ & present & 1 & 18.5 & $\sim 407$ & [29] \\
\hline Deltaic deposits & $>3$ & present & 0.08 & $8.3-56.2$ & $91 \pm 52$ & {$[1]$} \\
\hline Antarctic & $<1$ & present & 0.495 & & 0.725 & [30] \\
\hline Antarctic Peninsula & $<1$ & present & 0.1 & & 0.6 & [30] \\
\hline \multicolumn{7}{|c|}{ Circumpolar/boreal/Sub-Arctic regions } \\
\hline Circum-Arctic regions & $0-0.3$ & present & 18.782 & 33.95 & 191.29 & [29] \\
\hline Circum-Arctic regions & $0-0.3$ & present & 17.8 & 40.64 & $217 \pm 12$ & {$[1]$} \\
\hline Circum-Arctic regions & $0-1$ & present & 18.782 & 26.40 & 495.8 & [29] \\
\hline Circum-Arctic regions & $1-2$ & present & 17.8 & 19.94 & $355 \pm 81$ & [1] \\
\hline Circum-Arctic regions & $2-3$ & present & 17.8 & 11.63 & $207 \pm 42$ & {$[1]$} \\
\hline Circum-Arctic regions & $0-3$ & present & 18.782 & 18.17 & 1024 & [29] \\
\hline Circum-Arctic regions & $0-3$ & present & 17.8 & 19.38 & $1035 \pm 150$ & {$[1]$} \\
\hline Circum-Arctic regions & $0-3$ & present & 17.8 & & 1084 & {$[31]$} \\
\hline Circum-Arctic regions & $0-3$ & $\mathrm{LGM}^{1}$ & 29.3 & & 790 & [31] \\
\hline Boreal forest & $0-3$ & present & 12.0 & 4.17 & 150 & [32] \\
\hline Boreal and subarctic peatland & $0-1.1$ & present & 3.46 & 70.9-97.2 & $270-370$ & {$[33]$} \\
\hline Boreal and subarctic peatland & $0-2.3$ & present & 3.345 & 59.14 & 455 & {$[32]$} \\
\hline Boreal and subarctic peatland & $0-3$ & present & 3.46 & & $457-683$ & {$[31]$} \\
\hline Boreal and subarctic peatland & $0-3$ & LGM & 0.87 & & 30 & [31] \\
\hline \multicolumn{7}{|c|}{ Elevational permafrost regions (21.7-42.7 $\mathrm{PgC}$ ) } \\
\hline \multicolumn{7}{|l|}{ Qinghai Tibet Plateau (QTP) } \\
\hline QTP & $0-1$ & present & 1.35 & 12.81 & $17.3 \pm 5.3$ & [34] \\
\hline QTP & $0-2$ & present & 1.35 & 7.85 & $27.9 \pm 8.0$ & {$[34]$} \\
\hline QTP & $0-3$ & present & 1.35 & 3.78 & $33.3 \pm 9.4$ & [34] \\
\hline QTP & $>3$ & present & 1.35 & 3.77 & $127.2 \pm 37.3$ & {$[34]$} \\
\hline QTP & $0-2$ & present & 1.48 & 6.20 & $18.34 \pm 7.0$ & {$[36]$} \\
\hline QTP & $0-3$ & present & 1.06 & 11.45 & $36.4 \pm 2.5$ & [37] \\
\hline QTP & $0-3$ & present & 1.72 & 4.20 & 21.69 & [38] \\
\hline
\end{tabular}


Table 1. Cont.

\begin{tabular}{|c|c|c|c|c|c|c|}
\hline Regions & $\begin{array}{l}\text { Soil Horizons } \\
\text { or Depths (m) }\end{array}$ & $\begin{array}{l}\text { Time } \\
\text { Period }\end{array}$ & $\begin{array}{l}\text { Areal Extent } \\
\left(10^{6} \mathrm{~km}^{2}\right)\end{array}$ & $\begin{array}{c}\text { Soil Organic } \\
\text { Carbon Density } \\
\left(\mathrm{kg} \cdot \mathrm{m}^{-3}\right)\end{array}$ & $\begin{array}{c}\text { Carbon Stock } \\
(\operatorname{Pg} C)\end{array}$ & References \\
\hline \multicolumn{7}{|c|}{ Alpine/mountain regions } \\
\hline Alps & $0-1$ & present & $5 \times 10^{-3}$ & $7-35$ & $0.04-0.18$ & {$[39]$} \\
\hline Urals & $0-0.5$ & present & 0.13 & $7.7-39.3$ & $0.50-2.55$ & [40] \\
\hline Andes & $0-1$ & present & $2.6 \times 10^{-2}[1]$ & $5.2-88.3$ & $0.1-2.3$ & [41] \\
\hline Altai (Russia) & $0-1$ & present & $5.1 \times 10^{-5}$ & $2.0-3.2$ & & [42] \\
\hline
\end{tabular}

${ }^{1}$ Yedoma is an ice-rich loess, with volumetric ice content of $50-90 \%$ and organic carbon content of 2-5\%, mainly distributed in the northeastern part of North Siberia, Alaska, and Canada; ${ }^{2}$ LGM: Last Glacial Maximum (ca. 30-20 ka BP).

In the circumpolar permafrost regions $\left(17.8 \times 10^{6} \mathrm{~km}^{2}\right), 15 \%$ of global land area, SOC storage at depths of $0-3 \mathrm{~m}$ is estimated at $1035 \pm 150 \mathrm{Pg} \mathrm{C}$, equal to nearly one-third of global SOC storage at the same depths of $0-3 \mathrm{~m} \mathrm{[2].} \mathrm{Nearly} \mathrm{half} \mathrm{of} \mathrm{this} \mathrm{SOC} \mathrm{is} \mathrm{stored}$ at depths of $0-1 \mathrm{~m}$ in permafrost regions (472 $\pm 27 \mathrm{Pg} \mathrm{C}$ ), and SOC density declines downwards [11,34]. About 58-371 Pg C is found in the ice- and organic-rich and thick yedoma permafrost (at depths of 0-20 m) with an area extent less than $1.4 \times 10^{6} \mathrm{~km}^{2}$ [27]. In the High Arctic of $1.1 \times 10^{6} \mathrm{~km}^{2}$ in areal extent and comparable to that of yedoma regions, SOC is estimated at $34 \pm 16 \mathrm{Pg} \mathrm{C}(0-3 \mathrm{~m}$ in depth). The Antarctica is extensively covered with ice and with only a $0.35 \%$ ice-free area $\left(49,500 \mathrm{~km}^{2}\right)$. An SOC of $0.725 \mathrm{Pg} \mathrm{C}$ is estimated for Antarctic soils [30]. Spatial distribution of SOC in latitudinal permafrost regions indicates huge surface organic $C$ stocks $(<1 \mathrm{~m})$ and yedoma permafrost $C$ at depth and boreal/subarctic peatlands with the highest $C$ density $\left(59.1-97.2 \mathrm{~kg} \cdot \mathrm{m}^{-3}\right)$ among permafrost regions; this may potentially act as future $C$ sources for the atmosphere and aquatic systems. Since the Last Glacial Maximum (LGM at 30-20 ka B. P.), permafrost areal extents have declined substantially from the LGM to present, while the total SOC has increased by $\sim 300 \mathrm{Pg} \mathrm{C}$, with limited peatlands $\left(0.87 \times 10^{6} \mathrm{~km}^{2}\right)$ having been developed, forming a major atmospheric $C$ sink and sequestrating 427-653 Pg C from the atmosphere [31]. The SOC in yedoma permafrost regions during the LGM is estimated at $390-446 \mathrm{Pg} \mathrm{C}(>3 \mathrm{~m}$ in depth), in comparison with that of the present at 58-371 Pg C [27,28]. They may suggest a substantial carbon transfer ( $\mathrm{ca} .75-332 \mathrm{Pg} \mathrm{C}$ ) from the pedosphere and cryosphere to the atmosphere and hydrosphere. Therefore, permafrost $C$ has not been a net $C$ source since the LGM, but an internal $C$ transfer has occurred within northern permafrost $C$ pools [31].

Elevational permafrost covers an area of $2.5 \times 10^{6}-4.9 \times 10^{6} \mathrm{~km}^{2}$ [43]. The areal extent of the QTP (ca. $2.6 \times 10^{6} \mathrm{~km}^{2}$ ), about one-half of which is underlain by alpine and highplateau permafrost, accounts for nearly $70 \%$ of the areal extent of elevational permafrost in the world [44-47]. The SOC stock at depths of 0-3 $\mathrm{m}$ in plateau permafrost regions is estimated at 21.69-42.7 Pg C $[34,37,38]$. On the QTP and in other alpine/high-plateau permafrost regions, SOC content is generally low, with an average of $15.2 \pm 1.3 \mathrm{~kg} \mathrm{~m}^{-2}$, due to thin, sedimentary, or overburdened strata and poorly developed soil [43].

\subsection{Subsea Permafrost Carbon Storage}

During the LGM, the global sea level was 125 m (120-150 m) lower than that of the present [48]. The continental shelf of the Arctic Ocean, especially in Eastern Siberia and Alaska, is among the globally shallowest continental shelves, with an area extent of $\sim 3.0 \times 10^{6} \mathrm{~km}^{2}$ [2]. Under intermittent warming climates since the Late Pleistocene to the early Holocene, the rising of sea levels has resulted in frequently inundated arctic tundra ecosystems in the coastal terrains. In the Last Interglacial Stage (127-116 ka BP), global sea level was 9-11 $\mathrm{m}$ higher than that of the present [48]. As a result of submerging extensive LGM permafrost, a large stock of carbon is stored in the subsea permafrost domains. Sayedi et al. (2020) reported an organic carbon pool of $560 \mathrm{Pg} \mathrm{C} \mathrm{(170-740,90 \%} \mathrm{confidence}$ level) in subsea permafrost and of $45 \mathrm{Pg} \mathrm{C}(10-110)$ as methane hydrates [49]. The subsea 
permafrost has undergone degradation, transferring POC into both the atmosphere and the Arctic Ocean by coastal erosion [2]. An annual $\mathrm{CO}_{2}$ emission of $\sim 29 \mathrm{Tg} \mathrm{C}$ from the subsea permafrost in Arctic Siberia $\left(9.87 \times 10^{5} \mathrm{~km}^{2}\right)$ [50] and $38 \mathrm{Tg} \mathrm{C}(13-110)$ from the subsea permafrost has been estimated. Annual $\mathrm{CH}_{4}$ emission ranges from 3-18 $\mathrm{Tg} \mathrm{C}$ from the subsea permafrost $[49,51,52]$. Insufficient measurements of subsea permafrost largely increase uncertainties of estimates in subsea carbon storage and a wide range of carbon emission rates. Current assessments of $\mathrm{C}$ emission from subsea permafrost are more focused on atmospheric $\mathrm{C}$ emission, and they largely neglect the lateral $\mathrm{C}$ emission as dissolved/particulate organic carbon (DOC/PTOC) into the Arctic waters, which may underestimate the magnitude of subsea permafrost domains as a carbon source.

\subsection{Methane Hydrate Storages in Permafrost Regions}

Methane hydrates in permafrost regions have high potentials of $\mathrm{CH}_{4}$ emission due to the warming climate and greater unit warming power of $\mathrm{CH}_{4}$ in the atmosphere in comparison with that of $\mathrm{CO}_{2}$ [53]. An early estimation of $\mathrm{CH}_{4}$ hydrates in the Arctic permafrost regions was reported as $580 \mathrm{Pg} \mathrm{C} \mathrm{[54].} \mathrm{Later,} \mathrm{a} \mathrm{more} \mathrm{conservative} \mathrm{estimation}$ yielded a stock of $20 \mathrm{Pg} \mathrm{C}$ sequestered in Arctic permafrost regions [55]. Methane hydrates in subsea permafrost domains are $45 \mathrm{Pg} C$ [49]. Methane hydrates on the QTP amount to $175.4 \pm 39.2 \mathrm{Pg} \mathrm{C}$ [56]. However, this estimate awaits further confirmation and is highly uncertain. Methane hydrates in permafrost regions are mostly present in coastal areas in the Circum-Arctic regions [57]. Due to the high vulnerability to external alterations of temperature and pressure for the stabilization zone of methane hydrates [58], climate warming and natural disasters, such as volcanic abruption, submarine earthquake, subsea landslides, and large tsunami, can possibly destabilize methane hydrates and result in abrupt $\mathrm{C}$ emissions.

The carbon emission of destabilizing methane hydrates has been started [2]. Kretschmer et al. (2015) predicted an $0.03 \%$ loss of global inventory of methane hydrates ( $473 \mathrm{Tg} \mathrm{C})$ in the coming 100 years by melting hydrates [59]. Ruppel and Kessler (2017) emphasized that the large burial depth and high density of overlying materials of methane hydrates will relieve and retard the responses of methane hydrates to the warming climate [58]. Jin and Cheng (1997) noted that the $\mathrm{CH}_{4}$ emission from melting methane hydrates will not cause a significant impact on the global climate by 2100 [57]. However, Maslin et al. (2010) suggested disastrous positive feedbacks by abrupt $\mathrm{CH}_{4}$ emissions from destabilizing methane hydrates [53]. As shown in Figure 1d, the explosion of permafrost mounds on the Yamal Peninsula possibly has abruptly released a large amount of methane carbon into the atmosphere, and more than 400 sealed craters was recently found and reported from more than 7000 Arctic permafrost mounds [60]. 

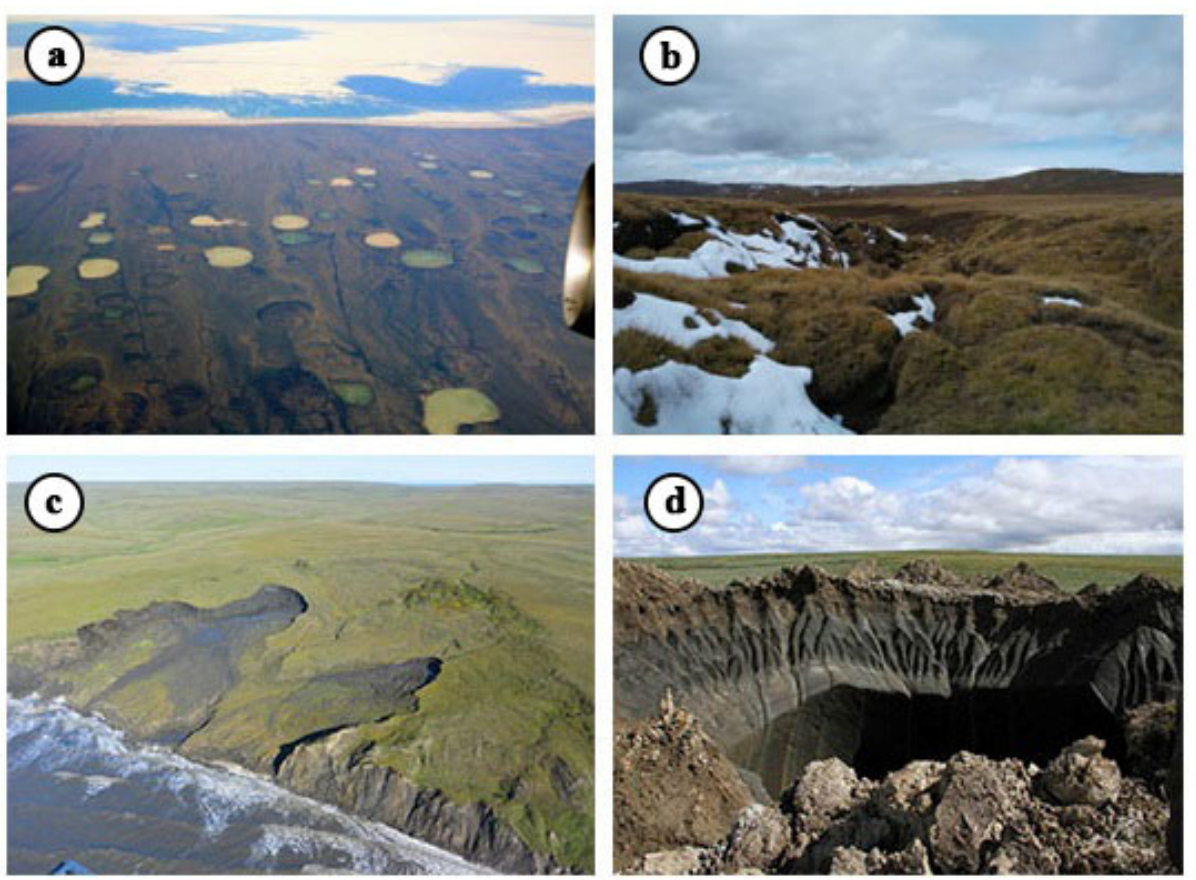

Figure 1. Thermokarst landscapes, which may also play important roles in carbon cycles in permafrost regions. Notes: (a) Thermokarst ponds near the Hudson Bay, Canada (Source: http: / / commons.sikimedia.org/wiki/File: Permafrost thaw ponds in Hudson Bay Canada near Greenland. Jpg, (accessed date 13 May 2021)); (b) thermal erosion gully near the Wanlong Worma Lake to the south of the Gyaring Lake in the southcentral Headwater Area of Yellow River on the northeastern Qinghai-Tibet Plateau, Southwest China (Photo by Dr. Qingfeng Wang); (c) coastal erosion and thermal slumps on the Qikiqtaruk-Herschel Island, Arctic Canada [14]; and (d) giant crater or sinkhole possibly formed by methane explosion on the Yamal Peninsula, northwestern Siberia (Source: https:/ / siberiantimes.com/science/casestudy/news/n0415-danger-of-methaneexplosions-on-yamal-peninsula-scientists-warn/) (accessed on 21 September 2021).

\section{Biodegradability of Permafrost Organic Carbon (POC)}

The biodegradability of POC determines the responsiveness and intensity of the feedback of permafrost $C$ stocks to climate warming. Both field observations and laboratory incubation have indicated a high biodegradability of POC. By pooling the incubation data sets from 121 observation sites and 23 ecosystems, Schädel et al. (2014) concluded that $20-90 \%$ of POC could be potentially mineralized within 50 incubation years [61]. Plaza et al. (2019) reported on the post-degradation organic C content in permafrost soils and found an annual rate of carbon loss as high as $4.5 \% \mathrm{yr}^{-1}$ [22]. In peatlands permafrost regions in Western Canada, newly thawed permafrost can result in a carbon loss rate ranging from $0.2 \%$ to $25 \%$ by 2100 [62].

Biodegradability of POC is determined by the properties of permafrost C, per se, as well as environmental factors, such as the microbial community (e.g., microbe abundance, community structure, and microbial types), SOC compositions, soil C/N ratio, soil hydrothermal conditions, and $\mathrm{Eh}$ and $\mathrm{pH}$, among others [61,63-65]. The incubation experiment is widely adopted to examine the mechanisms of POC biodegradation $[61,63,66]$. Mackelprang et al. (2011) analyzed impacts of permafrost thaw on functional genes and $\mathrm{CH}_{4}$ emission in incubation experiments, highlighting a rapid shift in functional genes and methanogenesis from frozen to thawed permafrost soils [67]. Xue et al. (2016) conducted an 1.5-year field warming condition/treatment and found markedly increased microbial richness and ecosystem respiration (38\%) in a tundra ecosystem underlain by permafrost [68]. Kwon et al. (2019) noted that the microbial community composition would be changed, and species richness were closely related to subsequent $C$ emissions upon thawing of permafrost [69]. Soil C/N ratio is also an important controller of POC $[61,65]$. 
Assembling and analysis of the data of aerobic soil incubations from 23 ecosystems in northern permafrost regions, it was evident that the slow cycling pool size was closely related with the soil $\mathrm{C} / \mathrm{N}$ ratios, an index for upscaling biodegradability of POC across the northern permafrost regions [61]. Ecosystem types and terrestrial vegetation biomes also influence the biodegradability of SOC and POC in permafrost regions by impacting compositions of SOC, increased alkyl C, and decreased recalcitrant aromatic C (lignin-derived) compounds [65,70,71]. After classifying the biodegradability of SOC in permafrost regions according to landscape classes and soil geochemical parameters (e.g., $\mathrm{C} / \mathrm{N}$ ratio and SOC content), Kuhry et al. (2020) also upscaled the potential greenhouse gas release from POC [65]. Soil hydrothermal conditions can also determine the decomposability and forms of $C$ emissions due to the aerobic or anaerobic environments [2,63,72]. Treat et al. (2015) collected the results from incubation experiments all over the northern permafrost regions and compared the results from different landscapes (vegetation types), soil properties (e.g., $\mathrm{pH}$ and soil types), and environmental factors (e.g., water table and temperature) to project the biodegradability of SOC emitted as methane [73].

Current data sets on incubation experiments are essential to quantify the biodegradability of POC across the northern permafrost regions. With a more comprehensive environmental factor data set of laboratory incubations for upscaling potential greenhouse gas release from POC, in addition to the processive knowledge of mechanisms of potential greenhouse gas release from $\mathrm{POC}, \mathrm{C}$ emission can be projected more accurately under uncertain future environmental conditions.

\section{Carbon Emissions in Regions of Degrading Permafrost}

\subsection{Atmospheric $\mathrm{CH}_{4}$ and $\mathrm{CO}_{2}$ Emission Induced by Permafrost Degradation}

Permafrost degradation can be manifested by a gradual mode, such as deepening active layer, shrinking areal extent of permafrost, and gradually thinning permafrost, and/or in an abrupt manner, such as the development of thermokarst, retrogressive thaw slumping, frozen debris flows, landslides due to active-layer detachment failures, and coastal thermal erosion, landslides, and collapses.

Atmospheric $\mathrm{CH}_{4}$ and $\mathrm{CO}_{2}$ emissions have been studied in permafrost regions in the arctic, subarctic, and boreal regions and on the QTP, with varied ecozones, including tundra, taiga forest, wetlands, peatlands, meadows, and steppes undergoing gradual permafrost degradation (e.g., [22,74-76]. In the arctic tundra ecosystem, based on the projected climate warming, Hollesen et al. (2011) reported a rate of $\mathrm{CO}_{2}$ emission at $\sim 40 \mathrm{~g} \mathrm{C} \mathrm{m}^{-2} \mathrm{yr}^{-1}$ at present and at $120-213 \mathrm{~g} \mathrm{C} \mathrm{m}^{-2} \mathrm{yr}^{-1}$ in the future. In low boreal wetlands [77], Roulet et al. (1992) reported $\mathrm{CH}_{4}$ emission rates up to $5.7 \mathrm{~g} \mathrm{C} \mathrm{m}^{-2} \mathrm{yr}^{-1}$ in beaver ponds and $3.6 \mathrm{~g} \mathrm{C} \mathrm{m}^{-2} \mathrm{yr}^{-1}$ in thicket swamps [74]. In boreal taiga permafrost regions, the average rate of $\mathrm{CO}_{2}$ emission was estimated at $19 \mathrm{~g} \mathrm{C} \mathrm{m}^{-2} \mathrm{yr}^{-1}$ [78]. In permafrost regions on the QTP, an early report on the amount (rate) of $\mathrm{CH}_{4}$ emission from the cold wetlands on the QTP was estimated at $0.7-0.9 \mathrm{Tg} \mathrm{C} \cdot \mathrm{yr}^{-1}\left(5.3-6.8 \mathrm{~g} \mathrm{C} \mathrm{m}^{-2} \mathrm{yr}^{-1}\right)$ [75]. This estimation was later updated as $0.215-0.412 \mathrm{Tg} \mathrm{C} \mathrm{yr}^{-1}\left(2.4-4.5 \mathrm{~g} \mathrm{C} \mathrm{m}^{-2} \mathrm{yr}^{-1}\right)$ based on more extensive and sophisticated studies [79]. Tao et al. (2007) reported rates of $\mathrm{CO}_{2}$ emission at $191.23 \mathrm{~g} \mathrm{C} \mathrm{m}^{-2} \mathrm{yr}^{-1}$ for alpine meadows in permafrost regions on the northeastern QTP [80].

An inconsistent regional estimation of carbon sink and/or source potentials under a warming climate has been reported for regions of degrading permafrost with varied ecosystem types. Virkkala et al. (2021) estimated the boreal regions as a carbon sink based on a net ecosystem exchange (NEE) of $-46 \mathrm{~g} \mathrm{C} \mathrm{m}^{-2} \mathrm{yr}^{-1}$, because of the photosynthetic offset of the released $\mathrm{CO}_{2}$ (soil respiration) [81] and the Arctic tundra served as a carbon source at $10 \mathrm{~g} \mathrm{C} \mathrm{m}^{-2} \mathrm{yr}^{-1}$ [82]. In the High-Arctic semi-desert regions, the carbon sink could strengthen by an order of magnitude under a warmer-wetter climate, but the summer carbon sink could be reduced by $55 \%$ under just a warming treatment [83]. In arctic peatlands permafrost regions, a low water table on peatlands under dry conditions had enhanced the POC feedback by adding atmospheric $\mathrm{CO}_{2}$ emissions. When the peatland 
water table remained low, Arctic peatlands would continue to serve as a potent $C$ sink [84]. Alases are mature thermokarst landscape covering $17 \%$ central Yakutia lowland [85]. Alases ecosystem with forest landcover is a reported small $\mathrm{CH}_{4} \operatorname{sink}\left(0.01-0.3 \mathrm{C} \mathrm{m}^{-2} \mathrm{yr}^{-1}\right)$, with wet-grass and ponded surface $\left(1.7-86.4 \mathrm{~g} \mathrm{C} \mathrm{m}^{-2} \mathrm{yr}^{-1}\right)$ [85,86].

In contrast to gradual permafrost degradation, abrupt permafrost degradation, such as thermokarst lakes (Figure 1a), thermal erosion gullies (Figure 1b), giant sinkholes (Figure 1c), active layer detachment landslide offshore in the Arctic Canada (Figure 1d), and retrogressive thaw-slump (Figure 2), occurs in periods of days to several years. Walter et al. (2007) found $\mathrm{CH}_{4}$ bubbling from northern lakes at a rate of $0.06 \pm 0.02 \mathrm{~g} \mathrm{CH}_{4} \mathrm{~m}^{-2} \mathrm{~d}^{-1}$ to the atmosphere [87]. In interior Alaska, methane emission from a thermokarst lake is reported at a rate of $0.15 \pm 0.02 \mathrm{~g} \mathrm{CH}_{4} \mathrm{~m}^{-2} \mathrm{~d}^{-1}$ [88]. $\mathrm{CH}_{4}$ emissions from thermokarst lakes from typical alas landscape are the reported highest rates in Arctic and subarctic regions [89]. Tanski et al. (2019) claimed that, when seawater eroded each gram of permafrost, $4.3 \pm 1.0 \mathrm{mg} \mathrm{CO}_{2}$ would be released into the atmosphere [14]. Parker et al. (2021) simulated the abrupt thaw of excess ice and found excess-ice meltwater is effective in high $\mathrm{CH}_{4}$ emission; once ice melt is connected to a subsurface flow, $\mathrm{CH}_{4}$ efflux is limited [90]. With an areal extent of $3.6 \times 10^{6} \mathrm{~km}^{2}$, Circum-Arctic thermokarst landscapes cover about $20 \%$ of the northern permafrost region, with a similar POC feedback comparable to the extensive and overall permafrost degradation in a gradual manner [91,92]. Increased wildfire frequency and scales also contribute to abrupt carbon emission [6,93]. In 2020, an ever highest temperature $\left(38^{\circ} \mathrm{C}\right)$ was recorded in the Arctic and $35 \%$ more $\mathrm{CO}_{2}$ was released by wildfires in comparison with that in 2019 and earlier recorded since 2003 [94].

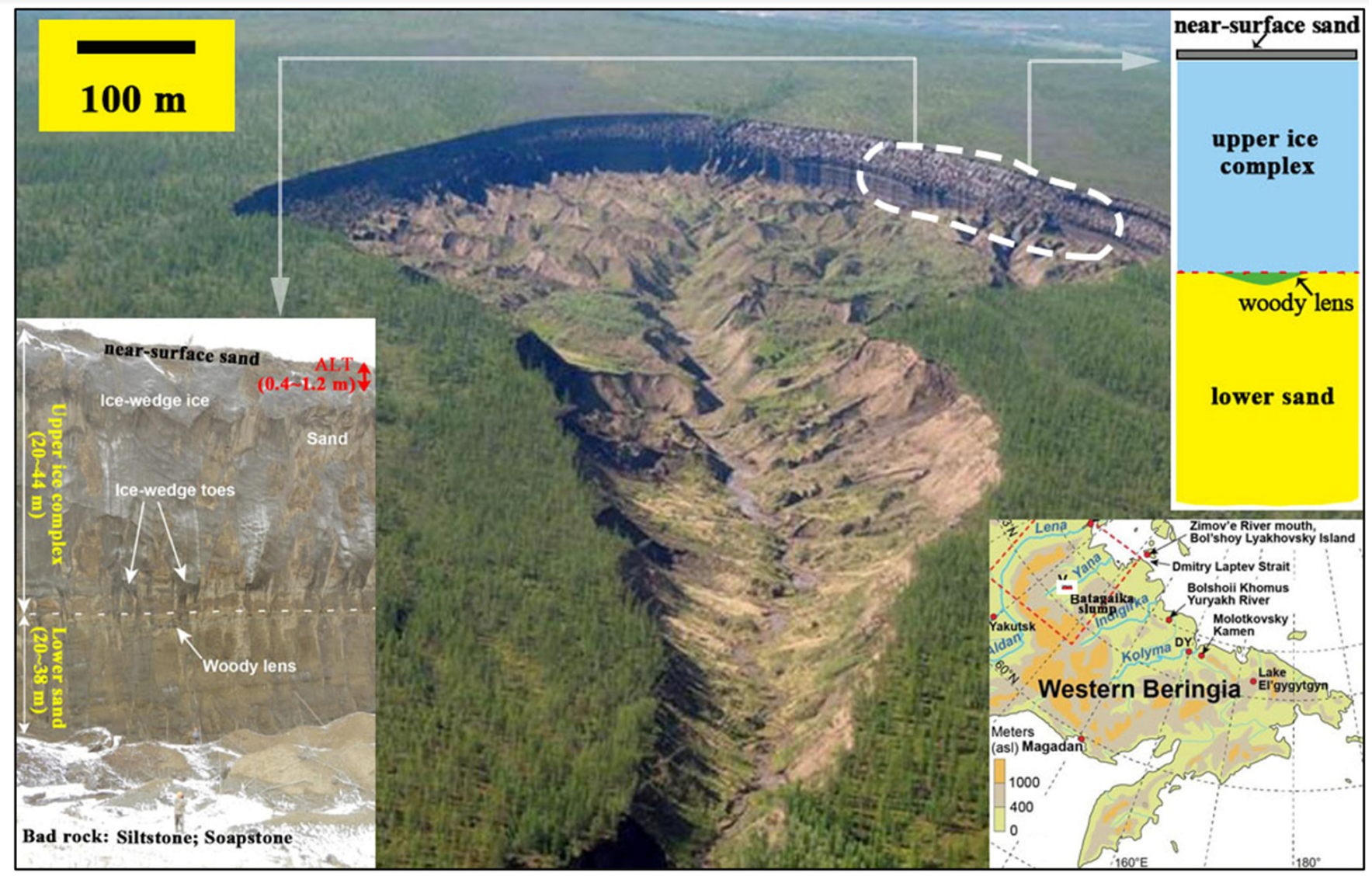

Figure 2. Mega-slump in the Batagaika taiga zone, Yana Uplands, eastern Siberia, Russia (revised from [18]). 


\subsection{Lateral Carbon Flux in Regions of Degrading Permafrost}

Under a warming climate, the lateral carbon flux, mainly in the form of dissolved organic carbon (DOC), particulate organic C (PTOC), and dissolved inorganic carbon (DIC), is also an important pathway of carbon emissions in regions of degrading permafrost [10,12,95-98].

After studying DOC concentrations in the rooting zone and groundwater in an Arctic taiga permafrost region, MacLean et al. (1999) reported a higher DOC in the rooting zone and a lower DOC in groundwater and springs [95]. This implies higher DOC fluxes in watersheds underlain by extensive permafrost in comparison with those by a limited presence of permafrost. This is probably due to the constrained water infiltration by permafrost. Walvoord and Striegl (2007) investigated changes in streamflow patterns in the Yukon River basin undergoing permafrost degradation and found a boosted groundwater contribution to streamflow $\left(0.7-0.9 \% \mathrm{yr}^{-1}\right)$, but without a pervasive change in annual flow regimes and subsequently a decreased DOC flux and increased DIC flux [99]. Giesler et al. (2014) studied long-term (1982-2010) aquatic DOC and DIC exports from permafrostdominated tundra catchments in northern Sweden and found a 9\% increase in DIC and no clear trend in DOC [100]. Guo et al. (2015) studied permafrost in a wetland catchment in northeastern China and suggested an increased DOC export from the catchment due to the warming-wetting climate [101]. By integrating the riverine chemistry coupled with a decadal data set of discharge, Tank et al. (2016) reported increasing trends of DOC $(+39.9 \%)$ and DIC (+12.5\%) fluxes in the Mackenzie River basin [102].

PTOC is also a major form of organic $C$ in rivers/streams in permafrost regions. McClelland et al. (2016) investigated PTOC flux from major Arctic rivers (e.g., Yenisey, Lena, Ob\&, Mackenzie, Yukon, and Kolyma) and found annual a PTOC export mainly concentrated in the spring (May and June) and winter PTOC export was less than 5\% of annual fluxes [103]. Lamoureux and Lafrenière (2014) confirmed their results, noting most annual PTOC flux was exported in the snow-melting season and permafrost disturbances dominated summer PTOC flux [104]. Other research reported dominance of vegetation and fluvial erosion on fluvial PTOC (e.g., [105]). McClelland et al. (2016) presumed that topographical inclination and water velocity impacted fluvial PTOC export [103]. The change trends of lateral DOC, PTOC, and DIC fluxes in some individual northern or elevational permafrost regions were collected and sketched in Figure 3. Evidently, there were no consistent change trends of in-stream DOC, PTOC, or DIC fluxes in permafrost catchments.

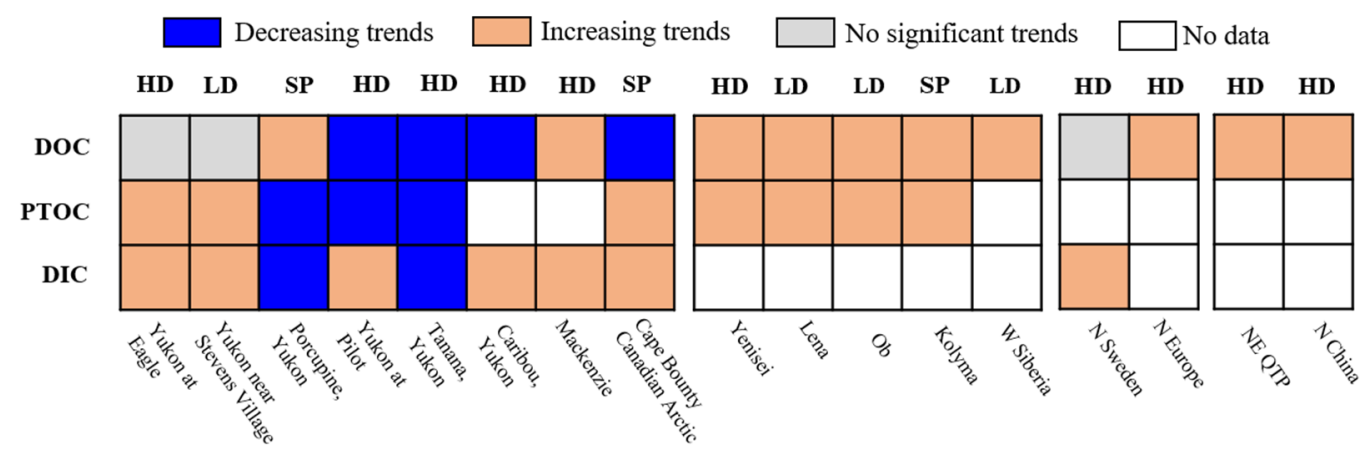

Figure 3. Changes in fluvial dissolved organic carbon (DOC), particulate organic carbon (PTOC), and dissolved inorganic carbon (DIC) exports in permafrost catchments. Note: The states of permafrost degradation in each estimated catchment are classified as High degree of permafrost degradation (HD), Low degree of permafrost degradation (LD), and Stable permafrost (SP) (data cited from [9, 101,105-112]).

Lateral C flux in regions of degrading permafrost is regulated and complicated by many geo-environmental factors (e.g., vegetation and snow cover, permafrost disturbances, hydrological pathways, and fluvial erosions). Discrepancy in estimates and/or predictions of changes in the permafrost environment in individual catchment and future climatic conditions lead to large uncertainties for changes in lateral $C$ dynamics in permafrost 
regions. However, several recent studies have pointed out the significance of atmospheric $\mathrm{C}$ emission from aquatic systems, probably due to important conduits of POC and methane emission potentials (e.g., $[15,113,114])$. Under a warming climate, permafrost degradation will alter the lateral flux of organic $C$ to aquatic systems. Thus, neglecting this lateral carbon flux will substantially underestimate the strength and channels of POC feedback to climate warming.

\section{Modeling and Projecting Permafrost Carbon Feedback to Climate Warming}

Permafrost $C$ stocks, biodegradability, and emission of permafrost carbon are baselines of simulating permafrost $C$ feedback to climate warming. Their studies can help make alerts for the risks of environmental changes and assure the economic and productive safety for policy makers [115-129].

Currently, studies on the model assessments of permafrost $C$ feedback to climate warming include Earth system models or coupled assessment models, and simulations on abrupt degradation feedback for climate warming are starting to be paid more attention. Waelbroeck et al. (1997) coupled hydrological and thermal models with a net- $\mathrm{CO}_{2}$ flux model for simulating the $\mathrm{C}$ accumulation/emission in a tundra ecosystem [115]. Khvorostyanov et al. (2008) integrated a 1-D soil model with a permafrost model for investigating carbon flux from yedoma terrains [116]. Koven et al. (2011) employed the Organising Carbon and Hydrology In Dynamic Ecosystems (ORCHIDEE), a terrestrial ecosystem model coupled with methanogenesis processes, and simulated the potential of permafrost carbon feedback to climate warming [117]. MacDougall et al. (2012) adopted an oceanic and terrestrial carbon circulation model by coupling the freeze-thaw processes, including permafrost carbon, to assess the additional warming by permafrost degradation [118]. By coupling the Lund-Potsdam-Jena managed Land (LPJmL), a global vegetation model, and permafrost modules, Schaphoff et al. (2013) examined the carbon sink and/or source functions in northern permafrost regions [119]. Von Deimling et al. (2015) developed a multi-pool permafrost carbon model based on the observed permafrost carbon properties and by taking into account of the abrupt permafrost degradation, e.g., formation of thermokarst lakes and landslides [120]. Burke et al. (2017) integrated the Joint UK Land Environment Simulator (JULES) and the ORCHIDEE-MICT (aMeliorated Interactions between Carbon and Temperature) with the Integrated Model of Global Effects of climate aNomalies (IMOGEN) to compare with the simulation results with and without permafrost carbon and quantify the additional warming from permafrost carbon [121]. Walter et al. (2018) integrated the Community Land Model (CLM) with a physically based thermokarst lake model for simulating permafrost carbon emission by taking into account of abrupt-thaw carbon emissions [122]. Detailed information on some examples of models for evaluating the feedback of permafrost carbon to climate warming are listed in Table 2.

Models of permafrost carbon emission have evolved from simulations of hydrothermal processes integrated with terrestrial carbon cycle models to Earth system models for climate modeling. However, there are still large uncertainties in modeling and projection results. Considerations of simulating the thermokarsting processes largely constrain the feedback of real-time permafrost carbon release to climate systems, which is a major part of permafrost carbon transmitted to the atmosphere [92,122]. Moreover, fire-induced permafrost degradation may be another major source of permafrost $C$ feedback to climate warming $[72,124]$. To date, this source from abrupt permafrost degradation is still missing from these carbon or ecosystem models. 
Table 2. Models' information on permafrost carbon feedback on climate warming.

\begin{tabular}{|c|c|c|c|c|}
\hline Coupled Models & Modeling Objectives & $\begin{array}{c}\text { Spatial } \\
\text { Resolution }\end{array}$ & $\begin{array}{c}\text { Temporal } \\
\text { Resolution }\end{array}$ & Reference \\
\hline $\begin{array}{l}\text { Hydrological and thermal model and } \\
\text { biogeochemical model }\end{array}$ & net- $\mathrm{CO}_{2}$ flux & $1.9^{\circ} \times 1.2^{\circ}$ & 1 day & {$[115]$} \\
\hline Permafrost model and 1-D soil model & $\begin{array}{l}\mathrm{CO}_{2} \& \mathrm{CH}_{4} \text { fluxes by } \\
\text { degrading permafrost }\end{array}$ & $0.5^{\circ} \times 0.5^{\circ}$ & 5 days & [116] \\
\hline $\begin{array}{c}\text { ORCHIDEE (Organizing Carbon and } \\
\text { Hydrology in Dynamics Ecosystems) model } \\
\text { and } \mathrm{CH}_{4} \text { module }\end{array}$ & net- $\mathrm{CO}_{2}$ and $\mathrm{CH}_{4}$ fluxes & $1.0^{\circ} \times 1.0^{\circ}$ & $3 \mathrm{~h}$ & {$[117,123]$} \\
\hline $\begin{array}{c}\text { UVic ESCM (University of Victoria Earth } \\
\text { System Climate Model) and permafrost model }\end{array}$ & $\begin{array}{l}\mathrm{CO}_{2} \text { flux by } \\
\text { permafrost degradation }\end{array}$ & $3.6^{\circ} \times 1.8^{\circ}$ & 5 days & [118] \\
\hline $\begin{array}{l}\text { LPJmL (Lund-Potsdam-Jena managed Land) } \\
\text { model and permafrost module }\end{array}$ & Net ecosystem carbon exchange & $0.5^{\circ} \times 0.5^{\circ}$ & 1 day & [119] \\
\hline Two-dimension multi-pool model & $\begin{array}{l}\mathrm{CO}_{2} \text { and } \mathrm{CH}_{4} \text { flux by } \\
\text { permafrost degradation }\end{array}$ & $2.0^{\circ} \times 2.0^{\circ}$ & 1 day & [120] \\
\hline $\begin{array}{c}\text { IMOGEN (Integrated Model Of Global Effects } \\
\text { of climatic aNomalies) }\end{array}$ & net- $\mathrm{CO}_{2}$ flux & $2.5^{\circ} \times 3.75^{\circ}$ & $30 \mathrm{~min}$ & [121] \\
\hline $\begin{array}{c}\text { CLM4.5BGC coupled with 3-D thermokarst } \\
\text { lake model }\end{array}$ & $\begin{array}{l}\mathrm{CO}_{2} \text { and } \mathrm{CH}_{4} \text { flux by } \\
\text { degrading permafrost }\end{array}$ & $0.5^{\circ} \times 0.5^{\circ}$ & 1 month & [122] \\
\hline
\end{tabular}

\section{Summary, Inadequacies, and Prospects}

Estimations of permafrost $C$ stocks have been intensively studied and data collection and computational procedures have been systematically and rapidly improving. There are still large uncertainties in estimating for the subsea permafrost $C$ and gas hydrates in permafrost regions due to the scarce data in these regions. Emission rates of permafrost carbon in response to climate warming largely depend on the biodegradability of permafrost carbon. The practical biodegradability of POC is a synergy of soil properties (e.g., $\mathrm{C} / \mathrm{N}$ ratio and SOC compositions) and geo-environmental factors (e.g., hydro-thermal conditions, $\mathrm{pH}$ and $\mathrm{Eh}$, and microbial community, among others). Permafrost $\mathrm{C}$ stocks and biodegradability data sets in Circum-Arctic regions have been developed and constructed. Projections of permafrost $C$ feedback to climate warming reveal an accelerated $C$ emission in permafrost regions from abrupt permafrost degradation and intensified or intensifying wildfires in permafrost regions.

Despite quantitative studies on organic carbon stocks and emissions in permafrost regions, the strength and timing of $C$ emission from northern permafrost regions in the future remain evasive. Inadequacies in the estimation of carbon stocks, particularly in subsea permafrost and gas hydrates in and under permafrost, tangle up the extents and rates of permafrost $C$ emissions. Laboratory incubation results for model upscaling are essential to constrain the potentials of permafrost carbon emissions under a warming climate, which are inadequate for current data sets on the decomposability of permafrost carbon. Knowledge of POC decomposability mechanisms seems inadequate. Present-day $\mathrm{CO}_{2}$ and $\mathrm{CH}_{4}$ emissions from northern permafrost regions have not been fully examined, which would be useful to verify modeling results and parameterization. Abrupt permafrost degradation contributes to a large amount of $\mathrm{C}$ emission. Aside from thermokarst processes, methane hydrate explosions and wildfire-induced abrupt $C$ feedbacks are also missing from current models. Aquatic systems contribute to one-half of $C$ emissions, of which the stocks of organic carbon and release potentials are often neglected from the existing studies.

According to those mentioned above, several prioritizations of the impact of permafrost degradation on carbon stocks and emissions are underlined here. (1) We suggest to greatly and rapidly improve the reliability for the estimation of $C$ stocks, especially in subsea and gas-hydrate permafrost regions. (2) Laboratory incubation should be widely conducted and related to environmental factors (e.g., microbial abundance and compositions) to establish and improve the permafrost carbon monitoring and incubation network and the associated databanks. (3) Observations of carbon emission in permafrost regions, 
including through remote sensing and data-miming techniques (e.g., machine learning algorithms) and in situ observations, are essential to verify the modeling performance; and, thus, should be greatly promoted and enhanced. (4) We propose to rapidly and extensively develop observation and modeling networks for abrupt permafrost degradation, such as those involving methane hydrate explosion and wildfire-induced permafrost degradation. (5) We advise to estimate the $C$ loads in aquatic systems and their release potentials for additional carbon feedback to climate warming.

Author Contributions: Writing—original draft preparation, Q.M.; writing—-review and editing, H.J.; supervision, H.J.; project administration, H.J.; funding acquisition, H.J. All authors have read and agreed to the published version of the manuscript.

Funding: This work was financially supported by the Natural Science Foundation of China (NSFC Grant No. 41871052) "Impacts of forest fires in the Da Xing'anling Mountains, Northeast China on the permafrost environment"; Key Program of NSFC Joint Foundation with Heilongjiang Province for Regional Development (Grant No. U20A2082) "Hydrothermal response mechanisms and carbon-cycling impacts of the degrading Xing'an permafrost"; and the Chengdong Leadership Research Funding of Northeast Forestry University (LJ2020-01) "Changes in Xing'an-Baikal permafrost and their impacts".

Institutional Review Board Statement: Not applicable.

Informed Consent Statement: Not applicable.

Data Availability Statement: Not applicable.

Acknowledgments: The authors are grateful to Emeritus Stuart A. Harris with the University of Calgary for his generous English editing and careful check in the technicality of this paper. The authors would also like to thank two unidentified reviewers for their insightful suggestions and professional comments in improving the paper.

Conflicts of Interest: The authors declare no conflict of interest.

\section{References}

1. Hugelius, G.; Strauss, J.; Zubrzycki, S.; Harden, J.D.; Schuur, E.A.G.; Ping, C.L.; Schirrmeister, L.; Grosse, G.; Michaelson, G.J.; Koven, C.D. Estimated stocks of circumpolar permafrost carbon with quantified uncertainty ranges and identified data gaps. Biogeosciences 2014, 11, 6573-6593. [CrossRef]

2. Schuur, E.A.G.; McGuire, A.D.; Schädel, C.; Grosse, G.; Harden, J.W.; Hayes, D.J.; Hugelius, G.; Koven, C.D.; Kuhry, P.; Lawrence, D.M.; et al. Climate change and the permafrost carbon feedback. Nature 2015, 520, 171-179. [CrossRef]

3. Zimov, S.A.; Davydov, S.P.; Zimova, G.M.; Davydova, A.I.; Schuur, E.A.G.; Dutta, K.; Chapin, F.S., III. Permafrost carbon: Stock and decomposability of a globally significant carbon pool. Geophys. Res. Lett. 2006, 33, L20502. [CrossRef]

4. Zimov, S.A.; Schuur, E.A.G.; Chapin, F.S., III. Permafrost and the global carbon budget. Science 2006, 312, 1612-1613. [CrossRef] [PubMed]

5. Köchy, M.; Hiederer, R.; Freibauer, A. Global distribution of soil organic carbon-Part 1: Masses and frequency distributions of SOC stocks for the tropics, permafrost regions, wetlands, and the world. Soil 2015, 1, 351-365. [CrossRef]

6. Intergovernmental Panel of Climate Change (IPCC). Climate Change 2021: The Physical Science Basis, Contribution of Working Group I to the Sixth Assessment Report of the Intergovernmental Panel on Climate Change; Intergovernmental Panel of Climate Change (IPCC): Cambridge, UK; New York, NY, USA, 2021.

7. Peng, X.; Frauenfeld, O.W.; Jin, H.; Du, R.; Qiao, L.; Zhao, Y.; Mu, C.; Zhang, T. Assessment of temperature changes on the Tibetan Plateau during 1980-2018. Earth Space Sci. 2021, 8, e2020EA001609. [CrossRef]

8. Schuur, E.A.G.; Bockheim, J.; Canadell, J.G.; Euskirchen, E.; Field, C.B.; Goryachkin, S.V.; Hagemann, S.; Kuhry, P.; Lafleur, P.M.; Lee, H.; et al. Vulnerability of permafrost carbon to climate change: Implications for the global carbon cycle. Bioscience 2008, 58, 701-714. [CrossRef]

9. Van Huissteden, J.; Dolman, A.J. Soil carbon in the Arctic and the permafrost carbon feedback. Curr. Opin. Environ. Sust. 2012, 4, 545-551. [CrossRef]

10. Hope, D.; Billett, M.F.; Cresser, M.S. A review of the export of carbon in river water: Fluxes and processes. Environ. Pollut. 1994, 84, 301-324. [CrossRef]

11. Fabre, C.; Sauvage, S.; Tananaev, N. Assessment of sediment and organic carbon exports into the Arctic ocean: The case of the Yenisei River basin. Water Resour. 2019, 158, 118-135. [CrossRef]

12. Ma, Q.; Jin, H.; Yu, C.; Bense, V. Dissolved organic carbon in permafrost regions: A review. Sci. China Earth Sci. 2019, 62, 349-364. [CrossRef] 
13. Meybeck, M. River transport of organic carbon to the ocean. In Flux of Organic Carbon by Rivers to the Oceans Report of a Workshop Held at the NAS Study Center, Woods Hole, MA, USA, 21-25 September 1980; CONF-8009140; United States Department of Energy: Washinton, DC, USA, 1981; pp. 219-269.

14. Tanski, G.; Wagner, D.; Knoblauch, C.; Fritz, M.; Lantuit, H. Rapid $\mathrm{CO}_{2}$ release from eroding permafrost in seawater. Geophys. Res. Lett. 2019, 46, 11244-11252. [CrossRef]

15. Rosentreter, J.A.; Borges, A.V.; Deemer, B.R.; Holgerson, M.A.; Liu, S.; Song, C.; Melack, J.; Raymond, P.A.; Duarte, C.M.; Allen, G.H.; et al. Half of global methane emissions come form highly variable aquatic ecosystem sources. Nat. Geosci. 2021, 14, 225-239. [CrossRef]

16. Jorgenson, M.T.; Shur, Y.L.; Pullman, E.R. Abrupt increase in permafrost degradation in Arctic Alaska. Geophys. Res. Lett. 2006, 33, L02503. [CrossRef]

17. Natali, S.M.; Watts, J.D.; Rogers, B.M.; Potter, S.; Ludwig, S.M.; Selbmann, A.K.; Sullivan, P.F.; Abbott, B.W.; Arndt, K.A.; Birch, L.; et al. Large loss of $\mathrm{CO}_{2}$ in winter observed across the northern permafrost region. Nat. Clim. Chang. 2019, 9, $852-857$. [CrossRef]

18. Murton, J.B.; Edwards, M.E.; Lozhkin, A.V.; Anderson, P.M.; Savvinov, G.N.; Bakulina, N.; Bondarenko, O.V.; Cherepanova, M.V.; Danilov, P.P.; Boeskorov, V. Preliminary paleoenvironmental analysis of permafrost deposits at Batagaika megaslump, Yana Uplands, northeast Siberia. Quat. Res. 2017, 87, 314-330. [CrossRef]

19. Fritz, M.; Opel, T.; Tanski, G.; Herzschuh, U.; Meyer, H.; Eulenburg, A.; Lantuit, H. Dissolved organic carbon (DOC) in Arctic ground ice. Cryosphere 2015, 9, 737-752. [CrossRef]

20. Elberling, B. Annual soil $\mathrm{CO}_{2}$ effluxes in the High Arctic: The role of snow thickness and vegetation type. Soil Biol. Biochem. 2007, 39, 646-654. [CrossRef]

21. Schuur, E.A.G.; Abbott, B.W.; Bowden, W.B.; Brovkin, V.; Camill, P.; Canadell, J.G.; Chanton, J.P.; Chapin, F.S., III; Christensen, T.R.; Ciais, P.; et al. Expert assessment of vulnerability of permafrost carbon to climate change. Clim. Chang. 2013, 119, 359-374. [CrossRef]

22. Plaza, C.; Pegoraro, E.; Bracho, R.; Celis, G.; Crummer, K.G.; Hutchings, J.A.; Hicks Pries, C.E.; Mauritz, M.; Natali, S.; Salmon, V.G.; et al. Direct observation of permafrost degradation and rapid soil carbon loss in tundra. Nat. Geosci. 2019, 12, 627-631. [CrossRef]

23. Chen, Y.; Liu, F.; Kang, L.; Zhang, D.; Kou, D.; Mao, C.; Qin, S.; Zhang, Q.; Yang, Y. Large-scale evidence for microbial response and associated carbon release after permafrost thaw. Glob. Chang. Biol. 2020, 27, 3218-3229. [CrossRef]

24. Monique, B. The buried carbon bomb. Nature 2021, 591, 360-362.

25. Ping, C.-L.; Michaelson, G.J.; Jorgenson, M.T.; Kimble, J.M.; Epstein, H.; Romanovsky, V.E.; Walker, D.A. High stocks of soil organic carbon in the North American Arctic region. Nat. Geosci. 2008, 1, 615-619. [CrossRef]

26. Burnham, J.H.; Sletten, R.S. Spatial distribution of soil organic carbon in northwest Greenland and underestimates of high Arctic carbon stores. Glob. Biogeochem. Cycles 2010, 24. [CrossRef]

27. Strauss, J.; Schirrmeister, L.; Grosse, G.; Wetterich, S.; Ulrich, M.; Herzschuh, U.; Hubberten, H.W. The deep permafrost carbon pool of the Yedoma region in Siberia and Alaska. Geophys. Res. Lett. 2013, 40, 6165-6170. [CrossRef] [PubMed]

28. Zhu, D.; Peng, S.; Ciais, P.; Zech, R.; Krinner, S.; Zimov, G. Simulating soil organic carbon in yedoma deposits during the Last Glacial Maximum in a land surface model. Geophys. Res. Lett. 2016, 43, 5133-5142. [CrossRef]

29. Tarnocai, C. Soil organic carbon pools in the northern circumpolar permafrost region. Glob. Biogeochem. Cycles 2009, 23, GB2023. [CrossRef]

30. Bockheim, J.G.; Haus, N.W. Distribution of organic carbon in the soils of Antarctica. In Soil Carbon; Hartemink, A.E., McSweeney, K., Eds.; Springer: Cham, Switzerland, 2014; pp. 373-380.

31. Lindgren, A.; Hugelius, G.; Kuhry, P. Extensive loss of past permafrost carbon but a net accumulation into present-day soils. Nature 2018, 560, 219-222. [CrossRef]

32. Bradshaw, C.J.A.; Warkentin, I.G. Global estimates of boreal forest carbon stocks and flux. Glob. Planet. Chang. 2015, 128, 24-30. [CrossRef]

33. Turunen, J.; Tomppo, E.; Tolonen, K.; Reinikainen, A. Estimating carbon accumulation rates of undrained mires in Finlandapplication to boreal and subarctic regions. Holocene 2002, 12, 79-90. [CrossRef]

34. Mu, C.; Zhang, T.; Wu, Q.; Peng, X.; Cao, B.; Zhang, X.; Cao, B.; Cheng, G. Editorial: Organic carbon pools in permafrost regions on the Qinghai-Xizang (Tibetan) Plateau. Cryosphere 2015, 9, 479-486. [CrossRef]

35. Shmelev, D.; Veremeeva, A.; Kraev, G.; Kholodov, A.; Spencer, R.; Walker, W.; Rivkinaet, E. Estimation and sensitivity of carbon storage in permafrost of North-Eastern Yakutia. Permafr. Periglac. Process. 2017, 28, 379-390. [CrossRef]

36. Zhao, L.; Wu, X.; Wang, Z.; Sheng, Y.; Fang, H.; Zhao, Y.; Hu, G.; Li, W.; Pang, Q.; Shi, J.; et al. Soil organic carbon and total nitrogen pools in permafrost zones of the Qinghai-Tibentan Plateau. Sci. Rep. 2018, 8, 3656. [CrossRef]

37. Ding, J.; Wang, T.; Piao, S. The paleoclimate footprint in the soil carbon stock of the Tibetan permafrost region. Nat. Commun. 2019, 10, 4195. [CrossRef] [PubMed]

38. Wang, D.; Wu, T.; Wu, X.; Wei, X.; Mu, C.; Li, R.; Hu, G.; Zou, D.; Zhu, X.; Chen, J.; et al. Soil organic carbon distribution for 0-3 m soils at $1 \mathrm{~km}^{2}$ scale of the frozen ground in the Third Pole Regions. Earth Syst. Sci. Data 2021. [CrossRef]

39. Egli, M.; Mirabella, A.; Sartori, G.; Zanelli, R.; Bischof, S. Effect of north and south exposure on weathering rates and clay mineral formation in alpine soils. Cetena 2006, 67, 155-174. [CrossRef] 
40. Dymov, A.A.; Zhangurov, E.V.; Startsev, V.V. Soil of the northern part of the Subpolar Urals: Morphology, physicochemical properties, and carbon and nitrogen pools. Euras. Soil Sci. 2013, 46, 459-467. [CrossRef]

41. Miller, D.C.; Birkeland, P.W. Soil catena variation along an alpine climatic transact, northern Peruvian Andes. Geoderma 1992, 55, 211-223. [CrossRef]

42. Pascual, D.; Kuhry, P.; Raudina, T. Soil organic carbon storage in a mountain permafrost area of Central Asia (High Altai, Russia). Ambio 2021, 50, 2022-2037. [CrossRef] [PubMed]

43. Bockheim, J.G.; Munroe, J.S. Organic carbon pools and genesis of alpine soils with permafrost: A review. Arct. Antarct. Alp. Res. 2014, 46, 987-1006. [CrossRef]

44. Ran, Y.; Li, X.; Cheng, G.; Zhang, T.; Wu, Q.B.; Jin, H.; Jin, R. Distribution of permafrost in China: An overview of existing permafrost maps. Permafr. Periglac. Process. 2012, 23, 322-333. [CrossRef]

45. Ran, Y.; Li, X.; Cheng, G. Climate warming over the past half century has led to thermal degradation of permafrost on the Qinghai-Tibet Plateau. Cryosphere 2018, 12, 595-608. [CrossRef]

46. Ran, Y.; Li, X.; Cheng, G.; Nan, Z.; Che, J.; Sheng, Y.; Wu, Q.; Jin, H.; Luo, D.; Tang, Z.; et al. Mapping the permafrost stability on the Tibetan Plateau for 2005-2015. Sci. China Earth Sci. 2021, 64, 62-79. [CrossRef]

47. Ran, Y.; Li, X.; Cheng, G.; Che, J.; Aalto, J.; Karjalainen, O.; Hjort, J.; Luoto, M.; Jin, H.; Obu, J.; et al. New high-resolution estimates of the permafrost thermal state and hydrothermal conditions over the Northern Hemisphere. Earth Syst. Sci. Data Discuss. 2021. [CrossRef]

48. Lambeck, K.; Rouby, H.; Purcell, A.; Sun, Y.; Sambridge, M. Sea level and global ice volumes from the Last Glacial Maximum to the Holocene. Proc. Natl. Acad. Sci. USA 2014, 111, 15296-15303. [CrossRef] [PubMed]

49. Sayedi, S.S.; Abbott, B.W.; Thornton, B.F.; Frederick, J.M.; Vonk, J.E.; Overduin, P.; Schädel, C.; Schuur, E.A.G.; Bourbonnais, A.; Demidov, N.; et al. Subsea permafrost carbon stocks and climate change sensitivity estimated by expert assessment. Environ. Res. Lett. 2020, 15, 124075. [CrossRef]

50. Vonk, J.E.; Sánchez-García, L.; Van Dongen, B.E.; Alling, V.; Kosmach, D.; Charkin, A.; Semiletov, I.P.; Dudarev, O.V.; Shakhova, N.; Roos, P.; et al. Activation of old carbon by erosion of coastal and subsea permafrost in Arctic Siberia. Nature 2012, 489, 137-140. [CrossRef]

51. Thornton, B.; Wik, M.; Crill, P. Double-counting challenges the accuracy of high-latitude methane inventories. Geophy. Res. Lett. 2016, 12, 569-577. [CrossRef]

52. Shakhova, N.; Semiletov, I.; Leifer, I.; Sergienko, V.; Salyuk, D.; Kosmach, D.; Chernykh, C.; Stubbs, D.; Nicolsky, V. Tumskoy Ebullition and storm-induced methane release from the East Siberian Arctic Shelf. Nat. Geosci. 2014, 7, 64-70. [CrossRef]

53. Maslin, M.; Owen, M.; Betts, R.; Day, S.; Jones, T.D.; Ridgwell, A. Gas hydrates: Past and future geohazard? Philos. Trans. Soc. A 2010, 368, 2369-2393. [CrossRef]

54. MacDonald, G.J. Role of methane clathrates in past and future climates. Clim. Chang. 1990, 16, 247-281. [CrossRef]

55. Ruppel, C. Permafrost-associated gas hydrate: Is it really approximately $1 \%$ of the global system? J. Chem. Eng. Data 2014, 60, 429-436. [CrossRef]

56. Wang, X.; Pan, L.; Lau, H.; Zang, M.; Li, L.; Zhou, Q. Reservoir volume of gas hydrate stability zones in permafrost regions of China. Appl. Energy 2018, 225, 486-500. [CrossRef]

57. Jin, H.; Cheng, G. Methane emissions in permafrost regions. Adv. Earth Sci. 1997, 12, 226-283. (In Chinese)

58. Ruppel, C.D.; Kessler, J.D. The interaction of climate change and methane hydrates. Rev. Geophys. 2017, 55, 126-168. [CrossRef]

59. Kretschmer, K.; Biastoch, A.; Rüpke, L.; Burwicz, E. Modeling the fate of methane hydrates under global warming. Glob. Biogeochem. Cycle 2015, 29, 610-625. [CrossRef]

60. Liesowska, A. More Than 400 Sealed 'Craters' Are Ticking Time Bombs from a Total 7000+ Arctic Permafrost Mounds. Available online: https: / / siberiantimes.com/other/others/news/more-than-300-sealed-craters-are-ticking-time-bombs-from-a-total7000-plus-arctic-permafrost-mounds (accessed on 30 June 2021).

61. Schädel, C.; Schuur, E.A.G.; Bracho, R.; Elberling, B.; Knoblauch, C.; Lee, H.; Luo, Y.; Shaver, G.R.; Turetsky, M.R. Circumpolar assessment of permafrost $\mathrm{C}$ quality and its vulerability over time using long-term incubation data. Glob. Chang. Biol. 2014, 20, 641-652. [CrossRef]

62. Treat, C.C.; Jones, M.C.; Alder, J.; Sannel, A.B.K.; Camill, P.; Frolking, S. Predicted vulnerability of carbon in permafrost peatlands with future climate change and permafrost thaw in Western Canada. Biogeosciences 2021, 126, e2020JG005872. [CrossRef]

63. Elberling, B.; Michelsen, A.; Schädel, C. Long-term $\mathrm{CO}_{2}$ production following permafrost thaw. Nat. Clim. Chang. 2013, 3, 890-894. [CrossRef]

64. Chen, L.; Liang, J.; Qin, S. Determinants of carbon release from the active layer and permafrost deposits on the Tibetan Plateau. Nat. Commun. 2016, 7, 13046. [CrossRef]

65. Kuhry, P.; Básra, J.; Blok, D.; Elberling, B.; Faucherre, S.; Hugelius, G.; Jørgensen, C.; Richter, A.; Šantrůčková, H.; Weiss, N. Lability classification of soil organic matter in the norhern permafrost region. Biogeosciences 2020, 17, 361-379. [CrossRef]

66. Schuur, E.A.G.; Vogel, J.G.; Crummer, K.G.; Lee, H.; Sickman, J.O.; Osterkamp, T.E. The effect of permafrost thaw on old carbon release and net carbon exchange from tundra. Nature 2009, 495, 556-559. [CrossRef] [PubMed]

67. Mackelprang, R.; Waldrop, M.P.; DeAngelis, K.M.; David, M.M.; Chavarria, K.L.; Blazewicz, S.J.; Rubin, E.M.; Jansson, J.K. Metagenomic analysis of a permafrost microbial community reveals a rapid response to thaw. Nature 2011, 480, 368-371. [CrossRef] 
68. Xue, K.; Yuan, M.; Shi, Z.J.; Qin, Y.; Deng, Y.; Cheng, L.; Wu, L.; He, Z.; Van Nostrand, J.D.; Bracho, R.; et al. Tundra soil carbon is vulnerable to rapid microbial decomposition under climate warming. Nat. Clim. Chang. 2016, 6, 595-600. [CrossRef]

69. Kwon, M.J.; Jung, J.Y.; Tripathi, B.M.; Göckede, M.; Lee, Y.K.; Kim, M. Dynamics of microbial communities and $\mathrm{CO}_{2}$ and $\mathrm{CH}_{4}$ fluxes in the tundra ecosystems of the changing Arctic. J. Microbiol. 2019, 57, 325-336. [CrossRef] [PubMed]

70. Wu, X.; Zhao, L.; Hu, G.; Liu, G.; Li, W.; Ding, Y. Permafrost and land cover as controlling factors for light fraction organic matter on the southern Qinghai-Tibetan Plateau. Sci. Total Environ. 2018, 613-614, 1165-1174. [CrossRef] [PubMed]

71. Li, F.; Peng, Y.; Chen, L.; Yang, G.; Abbott, B.W.; Zhang, D.; Fang, K.; Wang, G.; Wang, J.; Yu, J.; et al. Warming alters surface soil organic matter composition despite unchanged carbon stocks in a Tibetan permafrost ecosystem. Funct. Ecol. 2019, 34, 911-922. [CrossRef]

72. Natali, S.M.; Schuur, E.A.G.; Mauritz, M.; Schade, J.D.; Celis, G.; Crummer, K.G.; Johnston, C.; Krapek, J.; Pegoraro, E.; Salmon, V.G. Permafrost thaw soil moisture driving $\mathrm{CO}_{2}$ and $\mathrm{CH}_{4}$ release from upland tundra. J. Geophys. Res. Biogeosci. 2015, 120, 525-537. [CrossRef]

73. Treat, C.C.; Natali, S.M.; Ernakovich, J.; Iversen, C.M.; Lupascu, M.; Mcguire, A.D.; Norby, R.J.; Chowdhury, T.R.; Richter, A.; Šantrůčková, $\mathrm{H}$.; et al. A pan-Arctic synthesis of $\mathrm{CH}_{4}$ and $\mathrm{CO}_{2}$ production from anoxic soil incubations. Glob. Chang. Biol. 2015, 21, 2787-2803. [CrossRef]

74. Roulet, N.T.; Ash, R.; Moore, T.R. Low boreal wetlands as a source of atmospheric methane. J. Geophys. Res. Atmos. 1992, 97, 3739-3749. [CrossRef]

75. Jin, H.; Wu, J.; Cheng, G.; Nakano, T.; Sun, G.Y. Methane emissions from wetlands on the Qinghai-Tibet Plateau. Chin. Sci. Bull. 1999, 44, 2282-2286. [CrossRef]

76. Dutta, K.; Schuur, E.A.G.; Neff, J.C.; Zimov, S.A. Potential carbon release from permafrost soils of northeastern Siberia. Glob. Chang. Biol. 2006, 12, 2336-2351. [CrossRef]

77. Hollesen, J.; Elberling, B.; Jansson, P.E. Future active layer dynamics and carbon dioxide production from thawing permafrost layers in Northeast Greenland. Glob. Chang. Biol. 2011, 17, 911-926. [CrossRef]

78. Van Huissteden, J. Thawing Permafrost: Permafrost Carbon a Warm Arctic; Springer International Publishing: Cham, Swizerland, 2020.

79. Wei, D.; Tarchen, T.; Dai, D.; Wang, Y.; Wang, Y. Revisiting the role of $\mathrm{CH}_{4}$ emissions from alpine wetlands on the Tibetan Plateau: Evidence from two in situ measurements at 4758 and $4320 \mathrm{~m}$ above sea level. J. Geophys. Res. Biogeosci. 2015, 120, 1741-1750. [CrossRef]

80. Tao, Z.; Shen, C.; Gao, Q.; Sun, Y.; Yi, W.; Li, Y. Soil organic carbon storage and soil $\mathrm{CO}_{2}$ flux in the alpine meadow ecosystem. Sci. China Earth Sci. 2007, 50, 1103-1114. [CrossRef]

81. Virkkala, A.M.; Aalto, J.; Rogers, B.M.; Tagesson, T.; Treat, C.C.; Natali, S.M.; Watts, J.D.; Potter, S.; Lehtonen, A.; Mauritz, M. Statistical upscaling of ecosystem $\mathrm{CO}_{2}$ fluxes across the terrestrial tundra and boreal domain: Regional patterns and uncertainties. Glob. Chang. Biol. 2021, 27, 4040-4059. [CrossRef]

82. Jørgensen, C.; Johansen, K.; Westergaard-Nielsen, A.; Elberling, B. Net regional methane sink in High Arctic soils of northeast Greenland. Nat. Geosci. 2015, 8, 20-23. [CrossRef]

83. Lupascu, M.; Welker, J.M.; Seibt, U.; Maseyk, K.; Xu, X.; Czimczik, C.I. High Arctic reduces permafrost carbon feedbacks to climate warming. Nat. Clim. Chang. 2014, 4, 51-55. [CrossRef]

84. Voigt, C.; Marushchak, M.E.; Mastepanov, M.; Lamprecht, R.E.; Christensen, T.R.; Dorodnikov, M.; Jackowicz-Korczyński, M.; Lindgren, A.; Lohila, A.; Nykänen, H.; et al. Ecosystem carbon response of an Arctic peatland to simulated permafrost thaw. Glob. Chang. Biol. 2019, 25, 1746-1764. [CrossRef]

85. Takakai, F.; Desyatkin, A.; Larry, C.; Fedorov, A.; Desyatkin, R.; Hatano, $\mathrm{R}_{\text {. }} \mathrm{CH}_{4}$ and $\mathrm{N}_{2} \mathrm{O}$ emissions from a forest-alas ecosystem in the permafrost taiga forest region, eastern Siberia, Russia. J. Geophys. Res. Biogeosci. 2008, 113, G02002. [CrossRef]

86. Desyatkin, A.; Takakai, F.; Fedorov, R.; Nikolaeva, M.; Desyatkin, R.; Hatano, R. $\mathrm{CH}_{4}$ emission from different stages of thermokarst formation in Central Yakutia, East Siberia. Soil Sci. Plant Nut. 2009, 55, 558-570. [CrossRef]

87. Walter, K.M.; Smith, L.C.; Chapin, F.S. Methane bubbling from northern lakes: Present and future contributions to the global methane budget. Philos. Trans. A Math. Phys. Eng. Sci. 2007, 365, 1657-1676. [CrossRef]

88. Lindgren, P.R.; Grosse, G.; Walter, A.K.M.; Meyer, F.J. Detection and spatiotemporal analysis of methane ebullition on thermokarst lake ice using high-resolution optical aerial imagery. Biogeosciences 2016, 13, 27-44. [CrossRef]

89. Lara, H.; Bouchard, F.; Laurion, I.; Séjourné, A.; Marlin, C.; Hatté, C.; Costard, F.; Fedorov, A.; Desyatkin, A. Seasonal patterns in greenhouse gas emissions from thermokarst lakes in Central Yakutia (Eastern Siberia). Limnol. Oceanogr. 2020, 66, S98-S116.

90. Park, H.; Fedorov, A.; Konstantinov, P.; Hiyama, T. Numeriacal assessments fo excess ice impacts on permafrost aned greenhouse gases in a Siberian tundra site under a warming climate. Front. Earth Sci. 2021, 9, 704447. [CrossRef]

91. Olefeldt, D.; Goswami, S.; Grosse, G.; Hayes, D.; Hugelius, G.; Kuhry, P.; McGuire, A.D.; Romanovsky, V.E.; Sannel, A.B.; Schuur, E.A.; et al. Circumpolar distribution and carbon storage of thermokarst landscapes. Nat. Commun. 2016, 7, 13043. [CrossRef] [PubMed]

92. Turetsky, M.R.; Abbott, B.W.; Jones, M.C.; Anthony, K.W.; Olefeldt, D.; Schuur, E.A.G.; Grosse, G.; Kuhry, P.; Hugelius, G.; Koven, C.; et al. Carbon release through abrupt permafrost thaw. Nat. Geosci. 2020, 13, 138-143. [CrossRef]

93. Hu, F.; Higuera, P.; Walsh, J.; Chapman, W.; Duffy, P.; Brubaker, L.; Chipman, M. Tundra burning in Alaska: Linkages to climatic change and sea ice retreat. J. Geophys. Res. Biogeosci. 2010, 115. [CrossRef] 
94. Natali, S.M.; Holdren, J.P.; Rogers, B.M.; Treharne, R.; Duffy, P.B.; Pomerance, R.; MacDonald, E.N. Permafrost carbon feedbacks threaten global climate goals. Proc. Natl. Acad. Sci. USA 2021, 118, e2100163118. [CrossRef]

95. MacLean, R.; Oswood, M.W.; Irons, J.G., III; McDowell, W.H. The effect of permafrost on stream biogeochemistry: A case study of two streams in the Alaskan (U.S.A.) taiga. Biogeochemistry 1999, 47, 239-267. [CrossRef]

96. Guo, L.; Ping, C.-L.; Macdonald, R.W. Mobilization pathways of organic carbon from permafrost to arctic rivers in a changing climate. Geophys. Res. Lett. 2007, 34, 113603. [CrossRef]

97. Pawson, R.R.; Evans, M.G.; Allott, T.E.H.A. Fluvial carbon flux from headwater peatland streams: Significance of particulate carbon flux. Earth Surf. Proc. Land. 2012, 37, 1203-1212. [CrossRef]

98. Juutinen, S.; Väliranta, M.; Kuutti, V.; Laine, A.M.; Virtanen, T.; Seppä, H.; Weckström, J.; Tuittila, E.S. Short-term and long-term carbon dynamics in a northern peatland-stream-lake continuum: A catchment approach. J. Geophys. Res. Biogeosci. 2013, 118, 171-183. [CrossRef]

99. Walvoord, M.A.; Striegl, R.G. Increased groundwater to stream discharge from permafrost thawing in the Yukon River basin: Potential impacts on lateral export of carbon and nitrogen. Geophys. Res. Lett. 2007, 34. [CrossRef]

100. Giesler, R.; Lyon, S.W.; Mörth, C.M.; Karlsson, J.; Karlsson, E.M.; Jantze, E.J.; Destouni, G.; Humborg, C. Catchment-scale dissolved carbon concentrations and export estimates across six subarctic streams in northern Sweden. Biogeosciences 2014, 11, 525-537. [CrossRef]

101. Guo, Y.; Song, C.; Wan, Z.; Lu, Y.; Wang, L. Dynamics of dissolved organic carbon release from a permafrost wetland catchment in northeast China. J. Hydrol. 2015, 531, 919-928. [CrossRef]

102. Tank, S.E.; Striegl, R.G.; McClelland, J.W.; Kokelj, S.V. Multi-decadal increases in dissolved organic carbon and alkalinity flux from the Mackenzie drainage basin to the Arctic Ocean. Environ. Res. Lett. 2016, 11, 054015. [CrossRef]

103. McClelland, J.W.; Holmes, M.R.; Peterson, J.B.; Raymond, A.P.; Striegl, G.R. Particulate organic carbon and nitrogen export from major Arctic rivers. Glob. Biogeochem. Cycle 2016, 30, 629-643. [CrossRef]

104. Lamoureux, S.F.; Lafrenière, M.J. Seasonal fluxes and age of particulate organic carbon exported from Arctic catchments impacted by localized permafrost slope disturbances. Environ. Res. Lett. 2014, 9, 045002. [CrossRef]

105. Striegl, R.G.; Dornblaser, M.M.; Aiken, G.R.; Wickland, K.P.; Raymond, R.A. Carbon export and cycling by the Yukon, Tanana, and Porcupine rivers, Alaska. Water Resour. Res. 2007, 43, W02411. [CrossRef]

106. Worrall, F.; Burt, T. Time sreies analysis of long-term river dissolved organic carbon records. Hydrol. Process. 2004, 18, 893-912. [CrossRef]

107. Findlay, S.E.G. Increased carbon trnasport in the Hudson River: Unexpected consequance of nitrogen deposition? Front. Ecol. Environ. 2005, 3, 133-137. [CrossRef]

108. Frey, K.E.; Smith, L.C. Amplied carbon release form vast West Siberian peatlands by 2100. Geophys. Res. Lett. 2005,32, L09401. [CrossRef]

109. Striegl, R.G.; Aiken, G.R.; Dornblaser, M.M.; Raymond, P.A.; Wickland, K.P. A decreased in discharge-normailized DOC export by the Yukon River during summer through autumn. Geophys. Res. Lett. 2005, 32. [CrossRef]

110. Ma, Q. Research on In-Stream Dissolved Organic Carbon Dynamics and Mechanisms in the Source Area of the Yellow River on the Northeastern Qinghai-Tibet Plateau, Southwest, China. Ph.D. Thesis, Chinese Academy of Sciences, Lanzhou, China, 2020. (In Chinese with English abstract).

111. Mu, C.; Zhang, F.; Chen, X.; Ge, S.; Mu, M.; Jia, L.; Wu, Q.; Zhang, T. Carbon and mercury export from the Arctic rivers and response to permafrost degradation. Water Res. 2019, 161, 54-60. [CrossRef]

112. Beel, C.; Lamoureux, S.; Orwin, J.; Pope, M.; Scott, N. Differential impact of thermal and physical permafrost disturbances on High Arctic dissolved and particulate fluvial fluxes. Sci. Rep. 2020, 10, 11836. [CrossRef]

113. Serikova, S.S.; Pokrovsky, O.S.; Ala-Aho, P.; Kazantsev, V.; Kirpotin, S.N.; Kopysov, S.G.; Krickov, I.V.; Laudon, H.; Manasypov, R.M.; Shirokova, L.S.; et al. High riverine $\mathrm{CO}_{2}$ emissions at the permafrost boundary of Western Siberia. Nat. Geosci. 2018, 11, 825-829. [CrossRef]

114. Zhang, L.; Xia, X.; Liu, S.; Zhang, S.; Li, S.; Wang, J.; Wang, G.; Gao, H.; Zhang, Z.; Wang, Q.; et al. Significant methane ebullition from alpine permafrost rivers on the East Qinghai-Tibet Plateau. Nat. Geosci. 2020, 13, 349-354. [CrossRef]

115. Waelbroeck, C.; Monfray, P.; Oechel, W.C.; Hastings, S.; Vourlitis, G. The impact of permafrost thawing on the carbon dynamics of tundra. Geophys. Res. Lett. 1997, 24, 229-232. [CrossRef]

116. Khvorostyanov, D.V.; Krinner, G.; Ciaia, P.; Heimann, M.; Zimov, S.A. Vulnerability of permafrost carbon to global warming. Part I: Model description and role of heat generated by organic matter decomposition. Tellus B 2008, 60B, 250-264. [CrossRef]

117. Koven, C.D.; Ringeval, B.; Friedlingstein, P.; Ciais, P.; Cadule, P.; Khvorostyanov, D.; Krinner, G.; Tarnocai, C. Permafrost carbon-climate feedbacks accelerate global warming. Proc. Natl. Acad. Sci. USA 2011, 108, 14769-14774. [CrossRef] [PubMed]

118. MacDougall, A.H.; Avis, C.A.; Weaver, A.J. Significant contribution to climate warming from the permafrost carbon feedback. Nat. Geosci. 2012, 5, 719-721. [CrossRef]

119. Schaphoff, S.; Heyder, U.; Ostberg, S.; Gerten, D.; Heinke, J.; Lucht, W. Contribution of permafrost soils to the global carbon budget. Environ. Res. Lett. 2013, 8, 014026. [CrossRef]

120. Von Deimling, T.S.; Grosse, G.; Strauss, J.; Schirrmeister, L.; Morgenstern, A.; Schaphoff, S.; Meinshausen, M.; Boike, J. Observationbased modelling of permafrost carbon fluxes with accounting for deep carbon deposits and thermokarst activity. Biogeosciences 2015, 12, 3469-3488. [CrossRef] 
121. Burke, E.J.; Burke, E.J.; Ekici, A.; Huang, Y.; Chadburn, S.E.; Huntingford, C.; Ciais, P.; Friedlingstein, P.; Peng, S.; Krinner, G. Quantifiying uncertainties of permafrost carbon-cliamte feedbacks. Biogeosciences 2017, 14, 3051-3066. [CrossRef]

122. Walter, A.K.; Von Deimling, T.S.; Nitze, I.; Frolking, S.; Emond, A.; Daanen, R.; Anthony, P.; Lindgren, P.; Jones, B.; Grosse, G. 21st-century modeled permafrost carbon emissions accelerated by abrupt thaw beneath lakes. Nat. Commun. 2018, 9, 3262. [CrossRef]

123. Krinner, G.; Viovy, N.; De Noblet-Ducoudré, N.; Ogée, J.; Polcher, J.; Friedlingstein, P.; Ciais, P.; Sitch, S.; Prentice, C.I. A dynamic global vegetation model for studies of the coupled atmosphere-biosphere system. Glob. Biogeochem. Cycles 2005, 19, GB1015. [CrossRef]

124. Holloway, J.E.; Lewkowicz, A.G.; Douglas, T.A.; Li, X.; Turetsky, M.R.; Baltzer, J.L.; Jin, H. Impact of wildfire on permafrost landscapes: A review of recent advances and future prospects. Permafr. Periglac. Process. 2020, 31, 371-382. [CrossRef]

125. Li, X.Y.; Jin, H.J.; Wang, H.W.; Marchenko, S.S.; Shan, W.; Luo, D.L.; He, R.X.; Spektor, V.; Huang, Y.D.; Li, X.Y.; et al. Influences of wildfires on the permafrost environment: A review. Adv. Clim. Chang. Res. 2021, 12, 48-65. [CrossRef]

126. Saito, K.; Machiya, H.; Iwahana, G.; Ohno, H.; Yokohata, T. Mapping simulated circum-Arctic organic carbon, ground ice, and vulnerability of ice-rich permafrost to degradation. Progr. Earth Planet Sci. 2020, 7, 31. [CrossRef]

127. Yokohata, T.; Saito, K.; Ito, A.; Ohno, H.; Tanaka, K.; Hajima, T.; Iwahana, G. Future projection of greenhouse gas emissions due to permafrost degradation using a simple numerical scheme with a global land surface model. Prog. Earth Planet. Sci. 2020, 7, 56. [CrossRef] [PubMed]

128. Saito, K.; Machiya, H.; Iwahana, G.; Yokohata, T.; Ohno, H. Numerical model to simulate long-term soil organic carbon and ground ice budget with permafrost and ice sheets (SOC-ICE-v1.0). Geosci. Model Dev. 2021, 14, 521-542. [CrossRef]

129. Mekonnen, Z.; Riley, W.; Berner, L.; Bouskill, N.; Torn, M.; Iwahana, G.; Breen, A.; Myers-Smith, I.; Criado, M.; Liu, Y.; et al. Arctic tundra shrubification: A review of mechanisms and impacts on ecosystem carbon balance. Environ. Res. Lett. 2021, $16,053001$. [CrossRef] 